\title{
Back on track? Reassessing rail transport for California's perishable produce
}

\author{
Moving perishable produce by rail, rather than by truck, could provide significant benefits \\ for Californians.
}

Joshua Seeherman, Postdoctoral Researcher, California Partners for Advanced Transportation Technology (PATH), UC Berkeley

Karen Trapenberg Frick, Associate Professor, Department of City and Regional Planning, UC Berkeley

Juan Caicedo, Doctoral Student, Institute of Transportation Studies, UC Berkeley

Mark Hansen, Professor, Institute of Transportation Studies, UC Berkeley

A unit train of refrigerated cars filled with produce crosses the country.

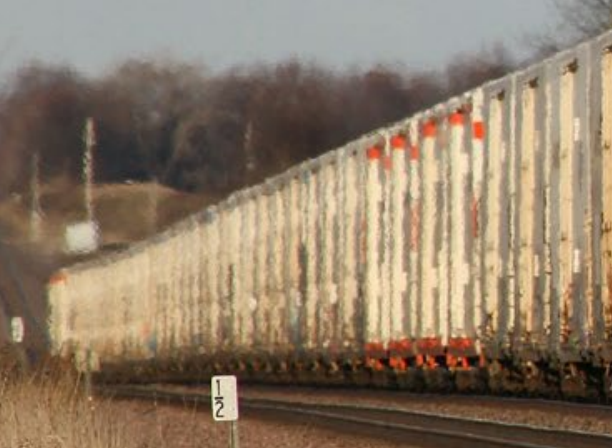

2 ailroads have long been an important component of California's freight transportation network.

For perishable produce in particular, the rail industry dominated until 1950 - but between 1960 and 1990, trucking took over. In 2016, California exported about $\$ 20$ billion in produce (CDFA 2017). But only 3\% of the state's exported perishable produce travels a majority of the distance to its destination by rail.

Transport of perishable produce has shifted from rail to trucking for complex reasons, but the change has not been altogether beneficial for Californians. Indeed, several negative externalities are associated with the truck-based transport of the overwhelming majority of the state's perishable produce. These externalities include increased air pollution, damage to infrastructure (primarily pavement) and truck crashes that harm public safety. If California growers increased their use of rail, significant benefits could therefore accrue to the public. Such a shift might also improve the agriculture sector's resiliency amid natural disasters. Additionally, if the price of diesel continues to increase and turnover among long-haul truck drivers remains high, a shift toward rail could benefit growers economically. Though a transition from truck to rail transport would entail several challenges, such obstacles could likely be overcome through concerted effort by growers, buyers, public agencies and railroads.

\section{Upward trend}

California perishables, as shown in table 1, traveled over 2 billion ton-miles by rail in 2013. Among items shipped by rail, durable items such as oranges and carrots predominated. For carrots, $26 \%$ of the state's total production traveled by rail; for celery, onion and broccoli, the corresponding figures were 5.6\%, 2.6\% and $2 \%$. (These figures were arrived at by dividing the tonnage of each commodity traveling by rail, as shown 
in table 1, by the state's total production of that commodity, derived from the state agricultural report for crop year 2013 [NASS 2015].)

In short, only a modest proportion of California's perishable produce travels by rail. But rail's importance may be on an upward trend. In the Central Valley, the railroad industry has made a significant effort to increase profits through transport of produce. Fresno, Tulare and Kern counties produce the majority of the state's orange crop and account for the majority of California's orange crop traveling by rail today. Figure 1 shows the percentage of oranges from these three counties that was transported by rail from 2005 to 2013; between 2007 and 2011, the percentage climbed substantially, to over $9 \%$ from under $2 \%$.

Why the increase? Likely because Railex, a rail and logistics provider, opened a carload rail facility in Delano (Kern County) in 2008. A carload is a full boxcar, approximately equivalent to 2.5 truckloads; the Delano facility was designed specifically for perishables. From Delano, "unit trains" composed exclusively of refrigerated boxcars (or "reefers") travel to New York in a guaranteed seven to eight days, a schedule competitive with trucking. The boxcars comprising these trains are typically filled at the Delano facility, but growers can also place their produce in refrigerated containers as soon as it is harvested. The containers can then be driven to a container ramp and loaded by crane onto a conventional container train or attached to a unit train dedicated to perishables. (In 2017, demonstrating renewed interest in the perishable produce market, Union Pacific purchased Railex and the Delano facility.)

\section{Potential benefits}

As part of research conducted for the Caltrans Division of Rail and Mass Transportation during 2015 and 2016, we examined peer-reviewed research that assessed various effects of rail travel as compared to truck travel (Seeherman and Hansen 2015). Working from these assessments, and calculating on the basis of the 2.1 billion ton-miles that California's perishable produce exports traveled by rail in 2013 , we estimated that rail travel saved the public approximately $\$ 19$ million by reducing four negative impacts: pavement damage, greenhousegas emissions, other polluting emissions and crashes.

To estimate these savings, we utilized existing lifecycle assessment analyses by Nahlik et al. (2015) and Facanha and Horvath (2007). These authors found that, due to the fuel efficiencies of rail as compared to trucks, greenhouse-gas emissions associated with freight trains were 0.44 pound lower per ton-mile than emissions associated with trucks ( 0.11 pound compared to 0.55 pound per ton-mile). We multiplied this difference by 2.1 billion ton-miles, resulting in a savings of roughly 900 million pounds of greenhouse-gas emissions. Taking into account current prices for carbon credits
TABLE 1. Top perishable produce commodities traveling by rail in 2013

\begin{tabular}{|c|c|c|c|}
\hline Commodity & $\begin{array}{l}\text { Average distance } \\
\text { traveled }\end{array}$ & Tons & Ton-miles \\
\hline & miles & & millions \\
\hline Carrots & 2,410 & 244,132 & 589 \\
\hline Fresh vegetables, unclassified & 2,482 & 224,160 & 556 \\
\hline Oranges & 2,466 & 151,100 & 373 \\
\hline Potatoes & 2,518 & 47,504 & 120 \\
\hline Celery & 2,403 & 47,096 & 113 \\
\hline Cantaloupes and melons & 2,500 & 41,648 & 104 \\
\hline Citrus, unclassified & 2,437 & 34,160 & 83 \\
\hline Onions & 2,336 & 23,672 & 55 \\
\hline Edible nuts in the shell & 2,765 & 22,080 & 61 \\
\hline Broccoli & 2,440 & 20,400 & 50 \\
\hline Total & 2,458 & 855,950 & 2,104 \\
\hline
\end{tabular}

* Average distance weighted by tonnage.

Source: Surface Transportation Board 2015.

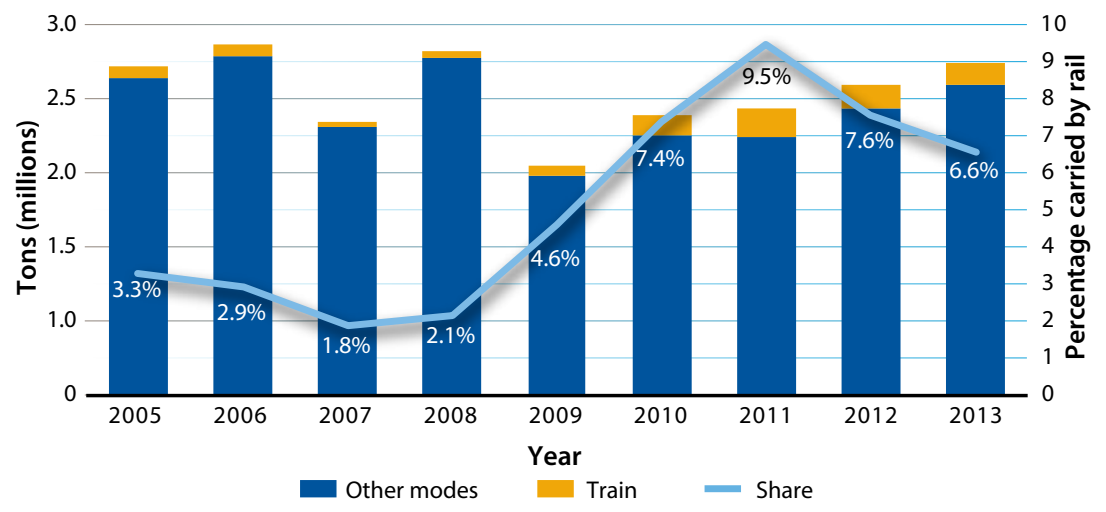

FIG. 1. Tonnage leaving California by rail - oranges. Source: Surface Transportation Board 2015.

on the California cap-and-trade market ( $\$ 14-\$ 15$ per metric ton, or about 2,200 pounds), this reduction in greenhouse-gas emissions equates to a savings in excess of $\$ 5.8$ million. We performed similar analyses for the other three categories. The savings were $\$ 1.8$ million for reduced pavement damage, $\$ 1.25$ million for health care savings related to reduced air pollution and $\$ 10.4$ million for crash reduction. Adding these to the $\$ 5.8$ million saved due to reduced emissions of greenhouse gases, the total estimated annual savings are $\$ 19.25$ million, or about $\$ 0.01$ per ton-mile. (Readers are invited to examine the technical report on the rail transport of perishable produce for more detailed calculations related to the non-greenhouse gas categories [Seeherman and Hansen 2015].)

This estimate considers only one year. It considers only the small fraction of California perishables that already travels by rail. Therefore, the scope for additional savings could be significant. In 2017, to take one example, Monterey County harvested enough broccoli 425,000 tons - to fill 17,000 trucks with 50,000 pounds of broccoli each (Monterey County 2017). This is an 
indication that increased transportation of perishable cargo by rail instead of truck could produce significant benefits both for infrastructure and for public health.

\section{Barriers to overcome}

A number of challenges stand in the way of achieving a meaningful shift from truck-based to rail-based transport of perishable produce. Though increased rail transport would yield savings for society, such savings can be challenging to visualize and would be difficult

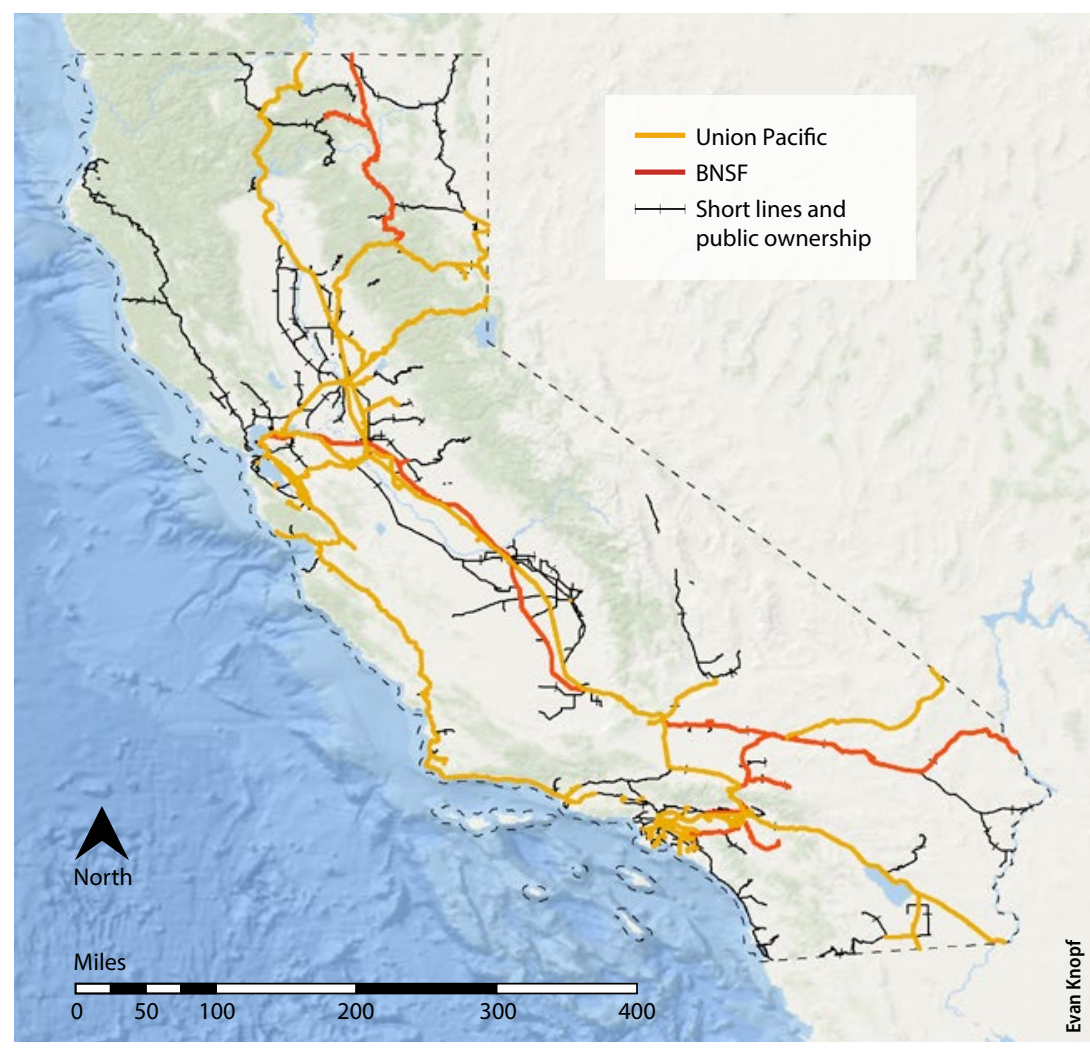

California is served by over 4,000 miles of track operated by the two long-haul interstate freight railroads, Union Pacific and BNSF, as well as an additional 800 miles operated by short-line railroads or public agencies.

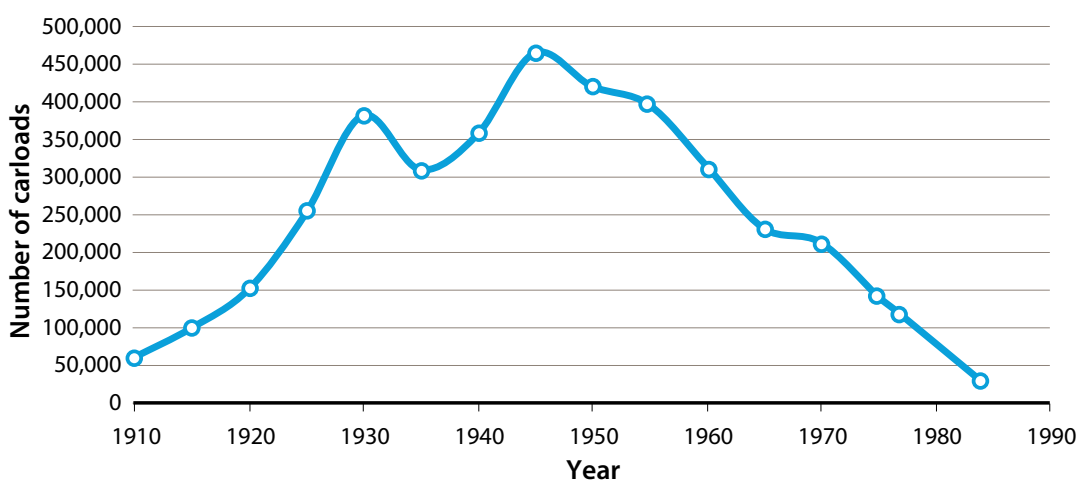

FIG. 2. Carload shipments by Pacific Fruit Express (PFE), 1910-1984. The steep decline in rail transport of produce from 1960 onward is well represented by the number of carloads (full boxcars, roughly equivalent to 2.5 truckloads) of produce moved by PFE, once among the nation's largest shippers of produce by rail. PFE was dissolved by its parent company in 1984. Source: Thompson et al. 2000. for growers to monetize. Perceived barriers include the current design of pallets, which are geared toward trucks and not trains; damage that produce can suffer due to the stronger vibrations involved in rail travel; spoilage resulting from travel delays; and a lack of needed infrastructure at rail terminals, particularly cold storage. But such barriers have sometimes been overcome in practice.

When growers contemplate transporting their produce via rail boxcars, they sometimes harbor concerns about pallets and empty space within the cars. Such concerns can be alleviated through the use of domestic intermodal containers - rail containers equal in size to regular truck trailers, and transferable between the two modes of transportation. Refrigerated intermodal containers can be fully loaded at growing sites before being driven to a rail terminal.

Certain types of produce - fairly durable items such as root vegetables (carrots, potatoes, onions) and citrus - have increasingly been shipped by rail in the last several years. Specific types of green vegetables, such as broccoli, can also tolerate the vibrations associated with rail and are potential candidates for future increases in rail transport. Indeed, another fragile but much more lucrative commodity - wine - has recently experienced significant growth in rail transport. Between 2003 and 2013, the amount of California wine transported by rail increased by about $30 \%$, to 1.8 from 1.4 million tons. Though boxed wine from San Joaquin County accounted for much of that increase, rail transport from Napa County significantly increased as well. This trend was advanced by a major grower, KendallJackson, which built a terminal for its rail shipments. In 2013, nearly half of all wine exports, by weight, left California on a train (Ball et al. 2015).

Another key concern regarding shipment of perishable produce involves time to market and the possibility of spoilage. Some delicate exports - such as berries, whole tomatoes and bagged salad - cannot tolerate delays during transport or interruptions in refrigeration. However, because of Union Pacific's new time guarantees for its Delano reefer unit train, many types of durable perishables - for example, carrots, citrus and broccoli - can now be safely transported by rail.

Some local governments are examining the potential benefits of increased capacity for cold rail storage of perishable produce. For example, the Association of Monterey Bay Area Governments (AMBAG) has worked with local growers and Union Pacific to evaluate the construction of an intermodal terminal and associated cold storage facility just south of Salinas (AMBAG 2011). Monterey County is one of the most productive fruit and vegetable counties in the United States but exports virtually all of its produce by truck. AMBAG's report regarding cold storage near Salinas presented two key findings:

1. Intermodal rail represents a transportation option that can help the local produce industry remain 
competitive - specifically by helping growers maintain relationships with wholesalers and distributors in an era when higher fuel costs and high turnover among long-haul truck drivers pose challenges for transporting produce by truck.

2. If increased use of rail transport removes from the Salinas Valley a portion of the trucks that now move produce out of the region, significant reductions in carbon emissions and air pollution will be realized.

The report estimated that if a cold storage facility were built near Salinas, demand would equate to about 180 to 200 domestic reefer containers per day, representing a small but significant fraction of the overall tonnage of produce exported from the county. The report estimated that use of reefer containers on this scale would eliminate the need for 46,800 full trucks per year; if each of those trucks is driven an average of approximately 3,000 miles, they collectively travel about 140 million miles. The report also found that switching from trucks to intermodal rail would not harm certain products currently transported by truck, notably broccoli and iceberg lettuce.

The report's authors, after examining truck and Union Pacific rate schedules, cited a transport savings to the East Coast of 5\%-10\%. The cost of building a dedicated intermodal ramp with cold storage in the Salinas Valley was estimated to be $\$ 20$ million. The report's authors concluded that "This is the right time to move forward with the use of rail for the shipment of agricultural products from the Salinas Valley region." Union Pacific reported that it was willing to move this new cargo. The company had capacity available on its route along the California coast, and major railroads are attempting to diversify their portfolios because revenues from coal transport are undergoing a long-term decline. Thus, for Union Pacific, perishable produce was attractive as a potential new commodity. The project lost significant momentum when the price of diesel dropped in 2013 - but with prices now inching back toward $\$ 4$ per gallon, growers may again push for modes of transport more efficient than trucking. (Both trucking and rail travel are primarily powered by diesel fuel, but because rail uses fuel more efficiently than trucking, rail travel becomes comparatively more attractive as diesel prices rise.)

\section{Compelling argument}

From 1960 to 1990, the vast majority of perishable produce transported out of California shifted from rail reefer cars to reefer trucks. Many of the factors behind this switch, such as differences in labor costs (due in part to higher rates of unionization among rail workers than truckers), persist to this day. Furthermore, after nearly 30 years of truck dominance, the forces of inertia make it challenging to reconfigure existing transport networks. Nevertheless, a compelling argument exists for moving at least some perishable produce back to rail. Rail boxcars and intermodal containers both exhibit a lower emissions profile than trucks; use of either will reduce traffic accidents and damage to freeway pavement; and both offer the flexibility of using a truck at either end of the rail journey. Rail transport of more durable produce types, such as oranges and root vegetables, has already proven successful, so a market for perishables already exists within the carload model (as shown in figure 1). Further growth in rail transport is likely to come from the intermodal market, which can accommodate a majority of produce types, including many green vegetables. As further noted by the AMBAG report, using modes of transport other than trucks could also improve resiliency in a disaster and increase the reliability of transport costs.

Given the obstacles to increased use of rail transport discussed above, a combined effort by railroads, growers, buyers and public agencies will be needed if movement of perishables is to transition from truck to rail. If diesel prices continue to increase and railroads achieve improvements in reliability and speed, rail could gain a greater share of the transport of perishable produce - a change that would most certainly reduce negative externalities and therefore benefit the public. CA

The authors thank Rebecca Brown for her helpful comments and revisions.

\section{References}

[AMBAG] Association of Monterey Bay Area Governments. 2011. Salinas Valley Truck to Rail Intermodal Facility Study. www. ambag.org/programs/freight/ Salinas\%20Valley\%20Truck\%20 to\%20Rail\%20Intermodal\%20

Feasibility\%20Study.pdf

Ball M, Trapenberg Frick K,

Seeherman J. 2015. Freight Case

Study: Wine. Caltrans Division

of Rail and Mass Transportation,

Rail Planning Branch. Sacra-

mento, CA. Available by request

from andrew.cook@dot.ca.gov.
[CDFA] California Department of Food and Agriculture. 2017. California Agricultural Statistics Review, 2015-2016. www.cdfa.ca.gov/statistics/ PDFs/2016Report.pdf

Facanha C, Horvath A. 2007. Evaluation of life-cycle air emission factors of freight transportation. Environ Sci Technol $41(20): 7138-44$. doi:10.1021/ es070989q
Monterey County. 2017. Monterey County Crop Report 2017: Honoring Our Past. www. co.monterey.ca.us/Home/ ShowDocument?id=65737 Nahlik MJ, Kaehr AT, Chester MV et al. 2015. Goods movement life cycle assessment for greenhouse gas reduction goals. J Ind Ecol 20(2):317-28. doi:10.1111/ jiec. 12277
[NASS] National Agricultural Statistics Service. 2015. California Agricultural Statistics 2013 Crop Year. www.cdfa.ca.gov/statistics/PDFs/CropYearStats2013 NASS.pdf

Seeherman J, Hansen M. 2015 Freight Case Study: Perishables. Caltrans Division of Rail and Mass Transportation, Rail Planning Branch. Sacramento, CA. Available by request from andrew.cook@dot.ca.gov.
Surface Transportation Board. 2015. National Freight Waybill Sample. www.stb.gov/stb/industry/econ_waybill.html Thompson AW, Church RJ, Jones BH. 2000. Pacific Fruit Express (2nd ed.). Wilton, CA: Signature Press. $472 \mathrm{p}$. 